\title{
PENGARUH PENGAWASAN DAN MOTIVASI TERHADAP LOYALITAS PERAWAT PELAKSANA DI RUANG RAWAT INAP RSU MITRA MEDIKA MEDAN
}

\author{
Chairul Syah Putra ${ }^{1 *}$, Arifah Devi Fitriani ${ }^{2}$, Asyiah Simanjorang ${ }^{3}$ \\ Program Studi Kesehatan Masyarakat Institut Kesehatan Helvetia \\ *Email: chairulsyahputra69@gmail.com
}

\begin{abstract}
ABSTRAK
Loyalitas merupakan proses yang timbul sebagai akibat keinginan untuk setia dan berbakti baik itu pada pekerjaannya, kelompok, atasan maupun pada perusahaannya, hal ini menyebabkan seseorang rela berkorban demi memuaskan pihak lain atau masyarakat. Desain penelitian adalah cross-sectional. Sampel penelitian adalah 74 perawat pelaksana yang bekerja di ruang rawat inap RSU Mitra Medika Medan. Hasil uji bivariat menunjukkan antara pengawasan dengan loyalitas diperoleh nilai $p($ Sig) $=0,000$, lebih kecil dari 0,05 maka $\mathrm{HO}$ ditolak dan dapat disimpulkan bahwa ada pengaruh antara pengawasan dan loyalitas perawat pelaksana di RSU Mitra Medika Medan. Hasil uji bivariat antara pengawasan dengan loyalitas diperoleh nilai $p($ Sig) $=0,000$ lebih kecil dari 0,05 maka Ho ditolak dan dapat disimpulkan bahwa ada pengaruh antara motivasi dan loyalitas perawat pelaksana di RSU Mitra Medika Medan. Disarankan kepada RSU Mitra Medika untuk meningkatkan pengawasan kepala ruangan dan sub bidang keperawatan kepada perawat pelaksana, dan meningkatkan motivasi perawat pelaksana sehingga loyalitas perawat pelaksana semakin baik dan RSU Mitra Medika semakin baik dalam memberikan pelayanan kesehatan terhadap pasien.
\end{abstract}

\section{Kata Kunci : RSU Mitra Medika, Cross Sectional, Loyalitas, Motivasi}

\begin{abstract}
Loyalty is the process of arising as a result of the desire to faithfully and serve either on its work, the group, boss and his company, this led to someone willing to make sacrifices for the sake of satisfying other parties or the public. Design research is a cross-sectional. The research sample was 74 managing nurses who worked in inpatient room RSU Partners Medical Medan. Test results showed bivariat between supervision with loyalty is earned value (GIS) $p=0.000$, smaller than 0.05 ; then $\mathrm{HO}$ is rejected and it can be concluded that there are influences of supervisory and loyalty between the implementing Partner in RSU nurse Medical Field. Test results of supervision with the loyalty between bivariat retrieved value $p(\mathrm{Sig})=0.000$, smaller than 0.05 ; then Ho denied and it can be concluded that there is influence between motivation and Loyalty Partner in implementing nurse RSU Medika terrain. It is recommended to the RSU Partners to improve the supervision of the head of the Medical and nursing areas to sub-sections implementing nurse, and increase the motivation of nurses implementing loyalty so that implementing the better nursing and Medical Partners increasingly $R S U$ good in providing the health service towards patients
\end{abstract}

Keywords : Mitra Medika Hospital, Cross Sectional, Loyalty, Motivation 


\section{PENDAHULUAN}

Memasuki milenium ketiga, Indonesia menghadapi berbagai perubahan dan tantangan strategis yang mendasar, yang perlu dipertimbangkan dalam melaksanakan pembangunan nasional termasuk Sumber Daya Manusia (man power). Perubahan dan tantangan strategis yang terjadi adalah berlangsungnya era globalisasi, perkembangan teknologi, transportasi, dan telekomunikasi informasi yang mengarah pada terbentuknya dunia tanpa batas. ${ }^{1}$

Loyalitas kerja atau kesetiaan merupakan salah satu unsur yang digunakan dalam penilaian karyawan yang mencakup kesetiaan terhadap pekerjaannya, jabatannya, dan organisasi. Loyalitas tinggi maka tujuan perusahaan akan tercapai dengan sendirinya. ${ }^{2}$

Pada suatu perusahaan, salah satu faktor penentu dalam loyalitas kerja karyawan adalah turnover, hal ini besar pengaruhnya bagi kelangsungan dan kemajuan perusahaan. Sebuah perusahaan dengan tingkat turnover yang tinggi menjadi tantangan khusus bagi pengembangan sumber daya manusia karena kejadian-kejadian tersebut tidak dapat diperkirakan. ${ }^{3}$

Adapun data turn over jumlah perawat pelaksana mulai dari Januari 2016 - Juli 2017 adalah sebagai berikut : Januari 2016 tidak ada perawat yang mengundurkan diri, Februari 2016 ada 2 perawat yang mengundurkan diri, Maret 2016 ada 2 perawat yang mengundurkan diri, April 2016 ada 1 perawat yang mengundurkan diri, Mei 2016 ada 1 perawat yang mengundurkan diri, Juni 2016 ada 1 perawat yang mengundurkan diri, Juli 2016 ada 1 perawat yang mengundurkan diri, Agustus 2016 ada 2 perawat yang mengundurkan diri, September 2016 ada 2 perawat yang mengundurkan diri, Oktober 2016 ada 4 perawat yang mengundurkan diri, November 2016 ada 1 perawat yang mengundurkan diri, Desember 2016 ada 4 perawat yang mengundurkan diri, Januari 2017 ada 6 perawat yang mengundurkan diri, Februari 2017 ada 3 perawat yang mengundurkan diri, Maret 2017 ada 3 perawat yang mengundurkan diri, April 2017 ada 1 perawat yang mengundurkan diri, Mei 2017 ada 1 perawat yang mengundurkan diri, Juni 2017 ada 1 perawat yang mengundurkan diri, Juli 2017 ada 11 perawat yang mengundurkan diri.

Adapun tujuan penelitian ini adalah untuk menganalisis pengaruh pengawasan dan motivasi terhadap loyalitas pada perawat pelaksana di rawat inap RSU Mitra Medika Medan.

\section{METODE DAN BAHAN}

Jenis penelitian ini adalah penelitian survei analitik (Explanatory Research) yaitu penelitian yang mencoba menggali bagaimana dan mengapa fenomena itu terjadi. Kemudian melakukan analisis dinamika korelasi antara fenomena, baik antara faktor resiko (independen) dan faktor efek (dependen). Survei analitik berupa bedah lintang (Cross Sectional). Data yang diperoleh melalui dengan penyebaran kuisioner yang selanjutnya diinterpretasikan dengan menggunakan rumus regresi linier berganda dengan bantuan program SPSS. ${ }^{4}$

Lokasi penelitian ini di Rumah Sakit Umum Mitra Medika yang beralamat di Jalan K.L Yos Sudarso Km 7,5 Tanjung Mulia Medan. Sampel adalah sebagian dari jumlah dan karakteristik yang dimiliki oleh populasi. Teknik pengambilan Sampel dalam penelitian ini adalah dengan menggunakan total populasi berjumlah 74 orang.

Penelitian ini menggunakan kuesioner sebagai alat ukur untuk mengukur variable independen dan variable dependen. Kuesioner berisi pertanyaan dan pernyataan terkait pengawasan dan motivasi terhadap loyalitas perawat pelaksana. Dilakukan analisis univariat untuk mendeskripsikan data pada tiap variabel dari hasil penelitian lewat distribusi frekuensi. Analisis bivariat untuk melihat hubungan masing - masing variabel independen dengan variabel dependen. Pada penelitian ini dengan Uji Chi-Square dengan batas kemaknaan perhitungan $p$ value $(0,05)$ untuk mengetahui hubungan antara variabel independen kategorik dengan variabel dependen kategorik. Apabila hasil perhitungan menunjukkan nilai $\mathrm{p}<\mathrm{p}$ value $(0,05)$ maka dikatakan $\mathrm{HO}$ ditolak, artinya kedua variabel secara statistik mempunyai hubungan yang signifikan. Analisis multivariat untuk menguji hubungan simultan lebih dari dua variabel. Pada penelitian ini, uji multivariat yang dilakukan adalah dengan regresi berganda binary (logistic regression) untuk memprediksi probabilitas dari suatu variabel dependen yang dikotomi dari sekelompok variabel independen. Adapun variabel independen yang dilakukan uji multivariat adalah yang memiliki $p$ value $<0,25$ dengan metode Enter. ${ }^{5}$ 
HASIL

Karakteristik Responden

Tabel 1. Distribusi Frekuensi Pengawasan Kepala Ruangan, Motivasi, loyalitas RSU Mitra Medika Medan

\begin{tabular}{lcc}
\hline Pengawasan & Frekuensi & Persentase \\
\hline Baik & 42 & 56,8 \\
Kurang & 32 & 43,2 \\
\hline Total & 74 & 100 \\
\hline Motivasi & Frekuensi & Persentase \\
\hline Baik & 47 & 63,5 \\
\hline Kurang & 27 & 36,5 \\
\hline Total & 74 & 100 \\
\hline Loyalitas & Frekuensi & Persentase \\
\hline Baik & 41 & 55,4 \\
\hline Kurang & 33 & 44,6 \\
\hline Total & 74 & 100 \\
\hline
\end{tabular}

Berdasarkan Tabel 1. Jumlah responden sebanyak 74 orang diketahui yang mempunyai penilaian pengawasan baik yaitu 42 orang $(56,8 \%)$ dan penilaian kurang yaitu 32 orang $(43,2 \%)$, Motivasi yang baik yaitu 47 orang $(63,5 \%)$ dan motivasi kurang baik yaitu 27 orang $(36,5)$, sedangkan loyalitas baik yaitu
41 orang $(55,4 \%)$ dan penilaian kurang yaitu 33 orang $(44,6 \%)$.

$\begin{array}{lrrr}\text { Tabulasi } & \text { Silang } & \text { Hubungan } & \text { Pengawasan } \\ \text { Kepala Ruangan } & \text { dengan } & \text { Loyalitas } \\ \text { Perawat } & \text { Pelaksana di Ruang } & \text { Rawat Inap } \\ \text { RSU } & \text { Mitra } & \text { Medika } & \text { Medan }\end{array}$

Tabel 2. Tabulasi Silang Hubungan Pengawasan Kepala Ruangan dengan Loyalitas Perawat Pelaksana di Ruang Rawat Inap RSU Mitra Medika Medan

\begin{tabular}{|c|c|c|c|c|c|c|c|}
\hline \multirow{3}{*}{ Pengawasan } & \multicolumn{4}{|c|}{ Loyalitas } & \multirow{2}{*}{\multicolumn{2}{|c|}{ Total }} & \multirow{3}{*}{ p (Sig) } \\
\hline & Kurang & & & & & & \\
\hline & $f$ & $\%$ & $f$ & $\%$ & $F$ & $\%$ & \\
\hline Kurang & 29 & 39,2 & 3 & 4,1 & 32 & 43,2 & 0,000 \\
\hline Baik & 4 & 5,4 & 38 & 51,4 & 42 & 56,8 & \\
\hline Total & 33 & 44,6 & 41 & 55,5 & 74 & 100 & \\
\hline
\end{tabular}

Berdasarkan hasil tabulasi silang antara pengawasan dengan loyalitas perawat pelaksana diperoleh data pengawasan kurang berjumlah 32 orang $(43,2 \%)$, memiliki loyalitas kurang yaitu 29 orang $(39,2 \%)$ dan memiliki loyalitas baik yaitu 3 orang $(4,1 \%)$. Pengawasan baik berjumlah 42 orang $(56,8 \%)$, memiliki loyalitas kurang yaitu 4 orang $(5,4 \%)$ dan memiliki loyalitas baik yaitu 38 orang $(51,4 \%)$. Hasil uji Tabel 3. Tabulasi Silang Hubungan Motivasi dengan Loyalitas Perawat Pelaksana di Ruang Rawat Inap RSU Mitra Medika Medan

\begin{tabular}{|c|c|c|c|c|c|c|c|}
\hline \multirow{3}{*}{ Motivasi } & \multicolumn{4}{|c|}{ Loyalitas } & \multirow{2}{*}{\multicolumn{2}{|c|}{ Total }} & \multirow{3}{*}{ p (Sig) } \\
\hline & \multicolumn{2}{|c|}{ Kurang } & \multicolumn{2}{|c|}{ Baik } & & & \\
\hline & $f$ & $\%$ & $f$ & $\%$ & $\mathbf{F}$ & $\%$ & \\
\hline Kurang & 25 & 33,8 & 2 & 2,7 & 27 & 36,5 & 0000 \\
\hline Baik & 8 & 10,8 & 39 & 52,7 & 47 & 63,5 & 0,000 \\
\hline Total & 33 & 44,6 & 41 & 55,4 & 74 & & 100 \\
\hline
\end{tabular}

Berdasarkan hasil tabulasi silang antara pengaruh motivasi terhadap loyalitas perawat pelaksana diperoleh data motivasi kurang berjumlah 27 orang $(36,5 \%)$, memiliki loyalitas statistik diperoleh nilai $p(\operatorname{Sig})=0,000$, lebih kecil dari 0,05 ; maka $\mathrm{HO}$ ditolak dan dapat disimpulkan bahwa ada pengaruh antara pengawasan dan loyalitas perawat pelaksana di RSU Mitra Medika Medan.

Tabulasi Silang Hubungan Motivasi dengan Loyalitas Perawat Pelaksana di Ruang Rawat Inap RSU Mitra Medika Medan

kurang yaitu 25 orang $(33,8 \%)$ dan memiliki loyalitas baik yaitu 2 orang $(2,7 \%)$. Motivasi baik berjumlah 47 orang $(63,5 \%)$, memiliki loyalitas kurang yaitu 8 orang $(10,8 \%)$ dan 
memiliki loyalitas baik yaitu 39 orang $(52,7 \%)$. Hasil uji statistik diperoleh nilai $p($ Sig $)=0,000$, lebih kecil dari 0,05; maka HO ditolak dan dapat disimpulkan bahwa ada pengaruh antara motivasi dan loyalitas perawat pelaksana di RSU Mitra Medika Medan.

\section{Analisis Multivariat}

Untuk menguji hubungan simultan lebih dua variable, analisis yang dipakai depedensi yang mana terdapat variabel bebas dan terikat dengan menggunakan model uji statistic multivariate regresi logistic berganda. Sebelum dilakukan uji multivariat dengan regresi logistik Tabel 4. Analisis Regresi Logistik Berganda

\begin{tabular}{lccccc}
\multicolumn{1}{c}{ Variabel Independen } & Nilai B & Nilai $P$ & Exp (B) & \multicolumn{2}{c}{$5 \%$ C. I for EXP(B) } \\
& & & & Lower & Upper \\
Pengawasan & 3.365 & .000 & 28.928 & 5.121 & 163.415 \\
Motivasi & 2.369 & .019 & 10.687 & 1.477 & 77.320 \\
Constant & -3.243 & .000 & .039 & & \\
\hline
\end{tabular}

Nilai $p$ value (Sig.) variabel pengawasan sebesar $0,000<0,05$ sehingga menolak $\mathrm{H} 0$ atau yang berarti variabel pengawasan kepala ruangan mempunyai pengaruh yang signifikan terhadap loyalitas perawat pelaksana di RSU Mitra Medika Medan. Besarnya pengaruh ditunjukkan dengan nilai $\operatorname{Exp}(B)$ sebesar 28,928. Perawat yang mendapatkan pengawasan yang baik maka 28,928 kali memiliki loyalitas yang baik. Nilai $p$ value (Sig.) variable motivasi sebesar $0,019<0,05$ sehingga menolak $\mathrm{H} 0$ atau yang berarti variabel motivasi mempunyai pengaruh yang signifikan terhadap loyalitas perawat pelaksana di RSU Mitra Medika Medan. Besarnya pengaruh ditunjukkan dengan nilai Exp(B) sebesar 10,687. Perawat yang memiliki motivasi baik maka 10,687 kali memiliki loyalitas yang baik.

\section{PEMBAHASAN}

Variabel pengawasan, penelitian ini menunjukkan bahwa hasil uji Chi Square $p$ value sebesar 0,000 , dengan demikian ada hubungan pengawasan dengan loyalitas perawat pelaksana di ruang rawat inap RSU Mitra Medika Medan. Berdasarkan hasil anlisis multivariat Nilai $p$ value (Sig.) variabel pengawasan sebesar $0,000<0,05$ sehingga menolak $\mathrm{H} 0$ atau yang berarti variabel pengawasan kepala ruangan mempunyai pengaruh yang signifikan terhadap loyalitas perawat pelaksana di RSU Mitra Medika Medan. Besarnya pengaruh ditunjukkan dengan nilai $\operatorname{Exp}(\mathrm{B})$ sebesar 28,928. Perawat metode "Enter", terlebih dahulu dilakukan uji kandidat untuk menyeleksi variabel independen manakah yang layak masuk pada uji multivariat. Adapun variabel independen yang layak adalah yang memiliki tingkat signifikansi atau $p$ value $<0,25$, yaitu pengawasan dan motivasi dengan $p$ value masing - masing sebesar 0,000 , dan 0,000 Kedua variabel yang layak tersebut kemudian dilakukan uji kandidat dengan melakukan satu persatu regresi sederhana antara masingmasing variabel independen terhadap variabel dependen yang mendapatkan pengawasan yang baik maka 28,928 kali memiliki loyalitas yang baik.

Hal ini sejalan dengan hasil penelitian Ruth Priyanka Sinambela dengan judul penelitian pengaruh pengawasan terhadap disiplin kerja perawat Rumah Sakit daerah Porsea Kabupaten Toba Samosir. Pengawasan yang dilakukan oleh atasan berpengaruh sangat signifikan terhadap disiplin perawat, hal ini terbukti dari hasil perhitungan regresi memperlihatkan bahwa $t$ hitung yang lebih besar dari $\mathrm{t}$ tabel yaitu Diketahui $\mathrm{t}$ hitung $(5,499)>$ t tabel $(2,030)$ dan Sig. $(0,000)<$ 0,05 . koefisien regresi untuk nilai $b=0,435$ artinya apabila pengawasan meningkat sebesar 1 satuan maka disiplin kerja perawat ruang VIP Rumah Sakit Umum Daerah Porsea meningkat 0,435 satuan. Nilai konstanta $a=$ 16,913 artinya apabila tidak ada faktor lain yang mempengaruhi pengawasan pada ruang VIP Rumah Sakit Umum Daerah Porsea maka disiplin perawat sebesar 16,913 satuan. Persamaan regresi diatas menunjukkan koefisien regresi dari variabel independent yaitu $b$ bertanda positif $(+)$, maka variabel pengawasan $(X)$ berpengaruh terhadap produktivitas karyawan. ${ }^{5}$

Dari 74 responden terdapat 43 perawat pelaksana dengan masa kerja $<1$ tahun sehingga kepala ruangan dapat memberi arahan yang baik terhadap perawat pelaksana yang ada. Dengan cara komunikasi ini kepala ruangan dapat mengajak perawat pelaksana untuk bekerja dengan baik untuk RSU Mitra Medika Medan sehingga menimbulkan rasa memiliki terhadap RSU Mitra Medika Medan. Perawat pelaksana $<1$ tahun sangat 
memerlukan arahan yang baik sehingga dapat bekerja sesuai prosedur opearsional yang berlaku di rumah sakit. Dengan perawat pelaksana bekerja dengan baik maka pelayanan terhadap pasien menjadi baik.

Variabel pengawasan, penelitian ini menunjukkan bahwa hasil uji Chi Square $p$ value sebesar 0,000 , dengan demikian ada hubungan motivasi dengan loyalitas perawat pelaksana di ruan rawat inap RSU Mitra Medika Medan. Berdasarkan hasil anlisis multivariate Nilai $p$ value (Sig.) variabel motivasi sebesar $0,019<0,05$ sehingga menolak $\mathrm{HO}$ atau yang berarti variabel motivasi mempunyai pengaruh yang signifikan terhadap loyalitas perawat pelaksana di ruang rawat inap RSU Mitra Medika Medan. Besarnya pengaruh ditunjukkan dengan nilai $\operatorname{Exp}(B)$ sebesar 10,687 . Perawat yang memiliki motivasi baik maka 10,687 kali memiliki loyalitas yang baik.

Hal ini sejalan dengan hasil penelitian Agung Pribadi, (2009), Analisis Pengaruh Faktor Pengetahuan, Motivasi, dan Persepsi Perawat tentang Supervisi Kepala Ruang terhadap Pelaksanaan Dokumentasi Asuhan Keperawatan di Ruang Rawat Inap RSUD Kelet Provinsi Jawa Tengah di Jepara. RSUD Kelet Jepara, adalah rumah sakit milik Pemerintah Provinsi Jawa Tengah yang relatif baru dalam melayani pasien umum. Rata-rata pelaksanaan pendokumentasian asuhan keperawatan masih rendah (58,9\%) jauh dari yang diharapkan $(80 \%)$.

Penelitian ini bertujuan menganalisis pengaruh faktor pengetahuan, motivasi, dan persepsi perawat tentang supervisi kepala ruang terhadap pelaksanaan dokumentasi asuhan keperawatan di RSUD Kelet Provinsi Jawa Tengah di Jepara. Metode yang digunakan studi cross sectional, jenis penelitian observasional dengan pendekatan kuantitatif. Sampel adalah seluruh populasi yang memenuhi kriteria, diberikan kuesioner untuk mengukur faktor-faktor pengetahuan perawat mengenai dokumentasi asuhan keperawatan, motivasi perawat, dan persepsi terhadap supervisi sebagai variabel bebas dan dinilai pelaksanaan dokumentasi asuhan keperawatan melalui dokumen rekam medik sebagai variabel terikat untuk selanjutnya dianalisa. Hasil Penelitian menunjukkan faktor pengetahuan perawat baik $51,6 \%$, tidak baik $48,4 \%$, faktor motivasi perawat baik $54,8 \%$, tidak baik $45,2 \%$, faktor persepsi mengenai supervisi baik $51,6 \%$, tidak baik $48,4 \%$, pelaksanaan dokumentasi asuhan keperawatan baik $58,1 \%$, tidak baik $41,9 \%$. Ada hubungan faktor pengetahuan perawat terhadap pelaksanaan dokumentasi asuhan keperawatan ( $p$ value $=0,007$ ), ada hubungan faktor motivasi perawat terhadap pelaksanaan dokumentasi asuhan keperawatan ( $p$ value $=$ 0,0001 ), ada hubungan faktor persepsi perawat mengenai supervisi terhadap pelaksanaan dokumentasi asuhan keperawatan ( $p$ value $=0,007$ ). Ada pengaruh secara bersama-sama antara faktor pengetahuan $(\mathrm{p}$ value $=0,044, \operatorname{Exp}(B)=$ $6,280)$ dan faktor persepsi perawat mengenai supervisi $(p$ value $=0,044, \operatorname{Exp}(B)=6,280$ ) terhadap pelaksanaan dokumentasi asuhan keperawatan. Ini dapat diartikan bahwa sebagian besar perawat pelaksana mempunyai faktor motivasi yang baik. Motivasi kerja yang dimiliki oleh pelaksana merupakan faktor intrinsik yang mempengaruhi individu untuk bekerja dengan baik. Motivasi tersebut akan terefleksi dalam pekerjaan mereka. Banyak perawat menikmati pekerjaan yang dilakukan bersamasama dalam satu tim, saling bersosialisasi dalam suasana kerja yang menyenangkan. Keanggotaan dalam organisasi profesi juga akan memberikan motivasi, mereka akan menemukan hal-hal baru dan solusi dalam memecahkan masalah klien baik dari organisasi tersebut maupun dari kolega mereka. ${ }^{6}$

Motivasi intrinsik dan ekstrinsik mempengaruhi dari loyalitas perawat pelaksana di RSU Mitra Medika Medan. Semakin baik motivasi perawat pelaksana maka semakin baik loyalitas perawat pelaksana di ruang rawat inap RSU Mitra Medika Medan. Dari hasil penelitian ini jumlah perawat pelaksana $<1$ tahun : 43 orang dari 74 perawat pelaksana di ruang rawat inap. Perawat pelaksana $<1$ tahun memiliki motivasi internsik yang baik atau dorongan yang baik dari dalam diri.

\section{KESIMPULAN}

Ada pengaruh pengawasan dan motivasi kepala ruangan terhadap loyalitas perawat pelaksana di ruang rawat inap di RSU Mitra Medika Medan.

\section{SARAN}

Diharapkan dapat melakukan penelitian terhadap sub variabel lain dari faktor individu yang tidak dapat diteliti pada penelitian ini. Demikian juga terhadap faktor lain selain faktor individu yang berpengaruh terhadap loyalitas di rumah sakit.

Diharapkan dapat melakukan penelitian dengan metode pengumpulan data yang lebih detil sehingga informasi yang diperoleh semakin dalam dan akurat. 


\section{DAFTAR PUSTAKA}

1. Gomes, \& Cardoso, F. Manajemen Sumber Daya Manusia. Yogyakarta. Terjemahan : Andi. 2013.

2. Hasibuan \& Malayu, S.P. Manajemen Sumber Daya Manusia, Edisi Revisi, Jakarta. Cetakan Ketiga, Bumi Aksara. 2011.

3. Nanggoy \& Harianti. Pengaruh Disiplin dan Loyalitas terhadap Kinerja Karyawan pada CV. Dwi Jaya Furniture Jepara. 2011[Internet] [Diakses oleh : Chairul Syah Putra, Tanggal 8 Agustus 2017]. Tersedia di http://www. distrodoc.com/274536-pengaruh-loyalitasdan-etos-kerja-terhadap-kinerja-karyawan

4. Muhammad, I. Panduan Penyusunan Karya Tulis IImiah Bidang Kesehatan Menggunakan
Metode Ilmiah. Bandung : Citapustaka Media Perintis: 2011

5. A Sinambela R,P, Pengaruh Pengawasan Terhadap Disiplin Kerja Perawat Rumah Sakit daerah Porsea Kabupaten Toba Samosir. Diakses oleh ChairulSyah Putra tanggal 28 September 2017 tersedia http://repository.unri.ac.id/xmlui/bitstream/ handle/123456789/4997/jurnal

6. Sari, Pribadi, A, Analisis Pengaruh Faktor Pengetahuan, Motivasi, dan Persepsi Perawat Tentang Supervisi Kepala Ruang Terhadap Pelaksanaan Dokumentasi Asuhan Keperawatan di Ruang Rawat Inap RSUD Kelet Provinsi Jawa Tengah di Jepara http:// eprints. undip. ac.id/16228/1/Agung Pribadi.pdf 